\title{
THE PARADOX OF HUMAN EQUIVALENT DOSE FORMULA: A CANONICAL CASE STUDY OF ABRUS PRECATORIUS AQUEOUS LEAF EXTRACT IN MONOGASTRIC ANIMALS
}

\author{
Saganuwan Alhaji Saganuwan, Patrick Azubuike Onyeyili \\ Department of Veterinary Physiology, Pharmacology and Biochemistry \\ College of Veterinary Medicine, University of Agriculture, \\ Makurdi, Benue State, Nigeria
}

Received 16 May 2015; Received in revised form 1 September 2015; Accepted 10 October 2015

\begin{abstract}
There is abundant literature on the toxicity of $A$. precatorius seeds. However there is a need to define the toxicity limit of the Abrus precatorius leaf in monogastric animals. Human Equivalent Dose (HED) which is equal to animal dose multiplied by animal $\mathrm{km}$ (metabolism constant) divided by human $\mathrm{km}$ was used to project the $\mathrm{LD}_{50}$ of fifteen monogastric animals, where human $\mathrm{km}$ factor is body weight $(\mathrm{kg})$ divided by body surface area $\left(\mathrm{m}^{2}\right)$. Human Equivalent No-observable Adverse Effect Doses were determined by multiplying the animal no-observable adverse effect dose by animal weight (Wa) divided by human weight (Wh). The $\mathrm{LD}_{50}$ of the aqueous leaf extract of Abrus precatorius in mice was estimated to be between 2559.5 and $3123.3 \mathrm{mg} / \mathrm{kg}$ body weight. The $\mathrm{LD}_{50}$ extrapolated from mouse to rat (1349.3-1646.6 mg/kg), hamster (1855.3-2264.1 mg/kg), guinea pig (1279.5-1561.4 mg/kg), rabbit (618.4-754.7 mg/kg), monkey $(593.7-724.5 \mathrm{mg} / \mathrm{kg})$, cat $(392.7-479.2 \mathrm{mg} / \mathrm{kg}), \mathrm{dog}$ and baboon (371.1-452.8 mg/kg), child (297-362 mg/kg) and adult human (197.8-241.5 mg/kg) body weight respectively could be a reality. The therapeutic safe dose range for the animals was $1-12.5 \mathrm{mg} / \mathrm{kg}$ body weight for a period of 7 days, but at a dose ( $\leq 200 \mathrm{mg} / \mathrm{kg}$ body weight) the leaf extract showed haematinic effect. However, at a higher dose $(>200 \mathrm{mg} / \mathrm{kg})$, the extract showed haemolytic activity in rats, whereas at a dose $(\geq 25.0 \mathrm{mg} / \mathrm{kg})$, the leaf extract might be organotoxic in hamster, guinea pig, rabbit, monkey, cat, dog, baboon, child and adult human if administered orally for a period of 7 days.
\end{abstract}

Key words: monogastric, toxicity, Abrus precatorius, mice, human

\section{INTRODUCTION}

Abrus precatorius is highly regarded as a universal panacea in a herbal medicine (49). The aqueous leaf extract of Abrus precatorius showed 99.4\% clearance of Plasmodium berghei in mice within 11 days (47), significant antimicrobial activity against Staphylococcus aureus, Streptococcus pyogenes, Klebsiella pneumoniae, Escherichia coli and Salmonella typhimurium (4, 42, 43). The plant showed significant inhibition of human

Corresponding author: Dr. Saganuwan Alhaji Saganuwan, $\mathrm{PhD}$ E-mail address: pharn_saga2006@yahoo.com

Present address: Department of Veterinary Physiology, Pharmacology and Biochemistry, College of Veterinary Medicine, University of Agriculture, P.M.B. 2373, Makurdi, Benue State, Nigeria Phone: +2347039309400

Copyright: (C) 2015 Saganuwan S.A.. This is an open-access article published under the terms of the Creative Commons Attribution License which permits unrestricted use, distribution, and reproduction in any medium, provided the original author and source are credited. Competing Interests: The authors have declared that no competing interests exist.

Available Online First: 4 November 2015

Published on: 15 March 2016

http://dx.doi.org/10.1515/macvetrev-2015-006 metabolic breast cancer cell line (MDA-MB 231). The ethanolic extract of Abrus precatorius leaves may be used in the management of asthma (52). It also inhibited acetylcholine-induced contractions of both toad rectus abdominis and rat phrenic nervediaphragm muscle preparations and caused flaccid paralysis in the young chicks (56). Both natural and heat denatured forms of abrusagglutinin are potential immunomodulators (54).

The leaves are used to cure fever, stomatitis, bronchitis (29), epilepsy (6), neuronal damage (35) and diabetes (13). Two triterpernoid saponins isolated from aerial parts of Abrus precatorius exhibited activity against inflammation (5), gonorrhoea, diarrhea and dysentery (8). The ethanol acetate of the leaf extract showed anti-serotonergic activity in frog fundus strip (11). The leaves also have astringent, emetic, antihelmintic, alexeteric and diuretic properties in addition to being useful in cough (32), pharyngodynia, pectoralgia (28), strangury and vitiated condition of vata $(25,29)$. Isoflavanquinone, abruquinone $\mathrm{B}$ and abruquinone 
$\mathrm{G}$ isolated from aerial parts of the plant exhibited antitubercular, antiplasmodial, antiviral and cytotoxic activities (30). The leaves are sweet tasting due to the presence of glycyrrhizin component. The leaves are also used for the treatment of scratches, sores and wounds caused by dogs, cats and mice. Fresh leaves may be pressed on the gum for the treatment of stomatitis, skin cancer and nervousness (8), suppuration, acne, boils, abscesses, tetanus, rabies (58), colic, convulsion (27), cough, sore throat and insomnia (33). Aqueous extract of the plant has haematinic and plasma expander effects in mice (38).

The leaf components are made of choline, trigonellin (III) (22), flavonoids, total glycosides, saponin glycosides, saponins and tannins in higher concentration, but alkaloids, steroids and cardiac glycosides are present in moderate concentration. Calcium (10.2mg), magnesium (5.2mg), Sodium (6.8mg), Potassium (10.8 mg), Phosphorous (2.4mg), nitrogen (30.5 $\mathrm{mg})$ (45), triterpenoid saponin, 3-0- $\beta$-D-glucopyranosyl-( $(\rightarrow 2)-\beta$, D-glucopyranosyl subprogenin $\mathrm{D}$ together with six triterpenoids, subprogenin $\mathrm{D}$, abrusgenic acid, triptotriterpenic acid $\mathrm{B}$, abruslactone $\mathrm{A}$, abrusogenin and abrusoside are also present (57). Other triterpenoids isolated are 20S, 220S)- $\beta$, 22-dihydroxycucubitacin, 24-diene-26, 29-dioc acid $\delta$ lactone, 3-0- (6'-methyl$\beta$-D-glucurunopyranosyl)-3 $\beta, \quad 22 \beta$-dihydroxylean12-en-29-oic acid methyl ester, 3-0 $\beta$-Dglucuronopyranosylsophoradiol methyl ester and sophoradiol (29). Abrusagglutinin, a low-toxicity protein present in every part of the plant is less lethal $\left(\mathrm{LD}_{50}=500 \mu \mathrm{g} / \mathrm{kg}\right)$ than abrin A $\left(\mathrm{LD}_{50}=20 \mu \mathrm{g} / \mathrm{kg}\right)$ (31).

The clinical features of Abrus precatorius leaf poisoning were pulmonary oedema and hypertension (16). The aqueous extract of $A$. precatorius leaf caused decreased levels of packed cell volume, haemoglobin concentration, red blood cell count, white blood cell count, mean corpuscular volume and mean corpuscular haemoglobin concentration in rats. The extract also resulted in increased levels of total serum protein, albumin, alanine amino transferase, aspartate amino transferase, alkaline phosphatase and total bilirubin. It also caused testicular degeneration characterized by decreased numbers of epithelial lining and reduction in sperm cells at dose range between 400 and $1600 \mathrm{mg} / \mathrm{kg}$ body weight (3). The foliage of Abrus precatorius contains abrin, which is among the most potent toxins. Clinical toxicosis was characterized by gastroenteritis, weakness and death $(2,10,20)$. Abrin is present in the leaf and is known to cause hyperactivity of physiological system (8). The parenteral $\mathrm{LD}_{50}$ of abrin in mice is less than $0.1 \mu \mathrm{g} / \mathrm{kg}$ (8). All parts of Abrus precatorius are toxic (9). 24
Acute toxicity study of aqueous extract of Abrus precatorius leaf in mice showed shallow respiration, sedation, weight loss, penile prolapsed and limbs paddling within 48 hours of extract administration. Haematological analysis revealed significant increased packed cell volume, red blood cell and white blood cell count (44). The biochemical analysis showed increased aspartate aminotransferase, alanine aminotransferase, alkaline phosphatase, creatinine, chloride ion, hypophospataemia, hyponatraemia, hypokalaemia and hypoglycaemia after 3 weeks of oral administration of the extract at dose range between 25.0 and $200 \mathrm{mg} / \mathrm{kg}$ body weight. At $12.5 \mathrm{mg} / \mathrm{kg}$ only the urea increased on the $7^{\text {th }}$ day of the extract administration (46). In vitro cytotoxicity assay of Abrus leaf against rat myoblast $\left(\mathrm{L}_{6}\right)$ cell line showed that chloroform fraction was the most toxic with inhibitory concentration $\left(\mathrm{IC}_{50}\right)$ value of $43.7 \mu \mathrm{g} / \mathrm{ml}$ followed by $\mathrm{n}$-hexane fraction $(44.3 \mu \mathrm{g} / \mathrm{ml})$. In vitro antiplasmodial assay against plasmodium chloroquiune-pyrimethanine resistant strain $\left(\mathrm{K}_{1}\right)$ showed that $\mathrm{n}$-hexane fraction has the best activity with $\mathrm{IC}_{50}$ value of $12.1 \mu \mathrm{g} / \mathrm{ml}$ followed by chloroform fraction $(23.0 \mu \mathrm{g} / \mathrm{ml})(40)$. The $\mathrm{LD}_{50}$ of oral and intraperitoreal aqueous extract of $\mathrm{Abrus}$ precatorius leaf in mice were 2559.5 to $3123.2 \mathrm{mg} / \mathrm{kg}$ and $866 \mathrm{mg} / \mathrm{kg}$ body weight respectively (45). In view of the toxic potential of Abrus precatorius and also in line with the principle of replacement, reduction and refinement, the toxicity potential of the plant was extrapolated from mice to other fifteen species of monogastric animals.

\section{MATERIAL AND METHODS}

Literature on the medicinal uses, phytochemical components, toxicological effects, therapeutic and toxic doses of aqueous extract of Abrus precatorius leaf was searched. The toxicological doses and toxic effects of Abrus precatorius aqueous leaf extract in rats as reported by Adedapo et al. (2) were compared to toxicological doses and toxic effects of aqueous extract of Abrus precatorius leaf in mice as reported by Saganuwan (39), Saganuwan and Onyeyili (46) and Saganuwan et al. (44). Oral $\mathrm{LD}_{50},(2559.5-3123.3 \mathrm{mg} / \mathrm{kg})$ safe $(12.5 \mathrm{mg} / \mathrm{kg})$ and toxic $(25-200 \mathrm{mg} / \mathrm{kg})$ doses of aqueous extract of Abrus precatorius leaf were translated from mice to human, hamster, rat, guinea pig, rabbit, monkey, cat, dog, baboon, ferret, marmoset, squirrel monkey, micro-pig, mini-pig and child weighing $0.02,60$, $0.08,0.15,0.4,1.8,3,7,10,12,0.3,0.35,0.6,20,40$, $20 \mathrm{~kg}$ body weight respectively $(17,37,41,48,51$, 55). The weights of the animals corresponded with the animal models used. The extract treatment doses 
$(400-1600 \mathrm{mg} / \mathrm{kg})$ in rats were translated to human treatment doses. Saganuwan (39), Saganuwan and Onyeyili (46) and Saganuwan et al. (45) used 10\% concentration of cold water extract of $A$. precatorius dry leaves. Adedapo et al. (2) used 50\% cold water macerated extract of Abrus precatorius leaf for their study. Twenty (20) gramme and $150 \mathrm{~g}$ weighed mouse and rat between $5-7$ weeks and $7-8$ weeks respectively were used for the studies.

Animal-human and human-animal dose translations of $\mathrm{LD}_{50}$, toxic and therapeutic doses of aqueous leaf extract of Abrus precatorius were determined using the human equivalent dose formula. Human Equivalent Dose (HED) is equal to animal dose multiplied by animal $\mathrm{km}$ factor divided by human $\mathrm{K}_{\mathrm{m}}$ factor. The $\mathrm{K}_{\mathrm{m}}$ factor is body weight $(\mathrm{kg})$ divided by body surface area $\left(\mathrm{m}^{2}\right)$. Human equivalent no-observable adverse effects dose is equal to animal no-observable adverse effect level (NOAEL) multiplied by animal weight (Wa) divided by human weight (Wh) to the power of 0.33 was used to confirm $12.5 \mathrm{mg} / \mathrm{kg}$ body weight of mice (relatively safe dose) translated to human and other animals' safe doses $(4,8,9,17,34,41,51,55)$.
A safety factor between $10^{\text {th }}$ and $1000^{\text {th }}$ was used to determine ideal safe therapeutic doses.

\section{RESULTS}

The range of $\mathrm{LD}_{50}$ estimated by Saganuwan (38, 39) was between 2559.5 and $3123.3 \mathrm{mg} / \mathrm{kg}$ body weight of mice. Adedapo et al. (3) did not conduct $\mathrm{LD}_{50}$ test on aqueous extract of Abrus precatorius leaf in rats. They investigated only haematological and biochemical effects of the extract on rats. The median lethal dose $(2559.5-3123.3 \mathrm{mg} / \mathrm{kg})$ of mice was translated to adult human $\mathrm{LD}_{50}$ (197.9$241.5 \mathrm{mg} / \mathrm{kg}$ ), child (297-362.3 mg/kg), minipig (211.4-258 mg/kg), micro-pig (274.9-335.4 $\mathrm{mg} / \mathrm{kg}$ ), squirrel monkey (1107.6-1351.7 mg/kg), marmoset $(1279.5-1561.4 \mathrm{mg} / \mathrm{kg})$, ferret $(1060.2-$ $1293.8 \mathrm{mg} / \mathrm{kg})$, baboon and $\operatorname{dog}(371.1-452.8 \mathrm{mg} / \mathrm{kg})$, cat (392.7-479.2 $\mathrm{mg} / \mathrm{kg})$, monkey (593.7-724.5 $\mathrm{mg} / \mathrm{kg})$, rabbit $(618.4-754.7 \mathrm{mg} / \mathrm{kg})$, guinea pig $(1279.5-1561.4 \mathrm{mg} / \mathrm{kg})$, rat (1349.3-1646.6 mg/kg) and hamster (1855.3-2264.1 $\mathrm{mg} / \mathrm{kg})$ respectively (Table 1).

Table 1. Mouse-human and human-other animals' extrapolated median lethal dose $\left(\mathrm{LD}_{50}\right)$ of aqueous leaf extract of Abrus precatorius

\begin{tabular}{|c|c|c|c|c|c|c|}
\hline S/No. & Species & $\begin{array}{c}\text { Body weight } \\
\text { (kg) }\end{array}$ & BSA (m2) & $K_{m}$ factor & $\mathrm{LD}_{50}(\mathrm{mg} / \mathrm{kg})$ & Toxicity rating \\
\hline 1. & Mouse & 0.02 & 0.007 & 2.9 & $2559.5-3123.3$ & Slightly toxic \\
\hline 2. & Hamster & 0.08 & 0.02 & 4.0 & $1855.3-2264.1$ & , \\
\hline 3. & Rat & 0.15 & 0.025 & 6.0 & $1349.3-1646.6$ & , \\
\hline 4. & Guinea pig & 0.4 & 0.069 & 5.8 & $1279.5-1561.4$ & , \\
\hline 5. & Rabbit & 1.8 & 0.15 & 12.0 & $618.4-754.7$ & " \\
\hline 6. & Monkey & 3.0 & 0.24 & 12.5 & $593.9-724.5$ & " \\
\hline 7. & Cat & 7.0 & 0.37 & 18.9 & $392.7-479.2$ & Moderately toxic \\
\hline 8. & Dog & 10 & 0.5 & 20.0 & $371.1-452.8$ & " \\
\hline 9. & Baboon & 12 & 0.6 & 20.0 & $371.1-452.8$ & ” \\
\hline 10. & Ferret & 0.3 & 0.043 & 7.0 & $1060.2-1293.8$ & ” \\
\hline 11. & Marmoset & 0.35 & 0.06 & 5.8 & $1279.5-1561.4$ & " \\
\hline 12. & Squirrel monkey & 0.6 & 0.09 & 6.7 & $1107.6-1351.7$ & " \\
\hline 13. & Micro-pig & 20 & 0.74 & 27.0 & 274.9-335.4 & ” \\
\hline 14. & Mini-pig & 40 & 1.14 & 35.1 & $211.4-258.0$ & ” \\
\hline 15. & Child & 20 & 0.8 & 25.0 & $297-362.3$ & " \\
\hline 16. & Adult human & 60 & 1.6 & 37.5 & $197.9-241.5$ & ", \\
\hline
\end{tabular}


The therapeutic doses $(12.5,25,50,100$ and $200 \mathrm{mg} / \mathrm{kg}$ ) in mice translated to $1,1.9,3.9,7.7$ and $15.5 \mathrm{mg} / \mathrm{kg}$ body weight in human. On the other hand the therapeutic doses $(400,800$ and $1600 \mathrm{mg} / \mathrm{kg}$ ) in rats translated to $58.7,117.3$ and $234.7 \mathrm{mg} / \mathrm{kg}$ body weight in human (Table 2). marmoset, squirrel, monkey, micro-pig, mini-pig, dog, baboon and mice to child translated doses are presented in Table 3.

At dose range between 400 and $1600 \mathrm{mg} / \mathrm{kg}$ body weight reported by Adedapo et al. (3), there was decreased $\mathrm{RBC}, \mathrm{PCV}$ and $\mathrm{Hb}$ which were

Table 2. Mouse-human and rat-human equivalent therapeutic doses of aqueous leaf extract of Abrus precatoirus

\begin{tabular}{lcc}
\hline Publications & Animal doses (mg/kg) & $\begin{array}{c}\text { Human equivalent doses } \\
\text { (mg/kg) }\end{array}$ \\
\hline Saganuwan and Onyeyili (38, 46), Saganuwan (37), & $12.5^{*}$ & $1.0^{*}$ \\
Saganuwan et al. (47) & 25 & 1.9 \\
& 50 & 3.9 \\
& 100 & 7.7 \\
\hline Adedapo et al. (3) & 200 & 15.5 \\
& 400 & 58.7 \\
\end{tabular}

* = Safe dose for a period of 7 days

Human-animal equivalent therapeutic dose translation showed that $1 \mathrm{mg} / \mathrm{kg}$ body weight of adult human translated to $1.1 \mathrm{mg} / \mathrm{kg}$ in mini-pig and $9.1 \mathrm{mg} / \mathrm{kg}$ body weight in hamster respectively. But, $1.9 \mathrm{mg} / \mathrm{kg}$ body weight in human translated to $2.02 \mathrm{mg} / \mathrm{kg}$ in mini-pig and $18.1 \mathrm{mg} / \mathrm{kg}$ in hamster respectively. However, $15.5 \mathrm{mg} / \mathrm{kg}$ in human translated to $16.6 \mathrm{mg} / \mathrm{kg}$ in micro-pig and $145.0 \mathrm{mg} / \mathrm{kg}$ in hamster (Table 3). Human to hamster, rat, guinea-pig, rabbit, monkey, cat, baboon, ferret, increased in mice $(40,44)$. White blood cells and lymphocytes were decreased in rat (3) (Table 4).

Alanine aminotransferase, aspartate aminotransferase, alkaline phosphatase, protein, albumin, globulin, albumin/globulin ratio were reported to have increased in rats and mice $(3,46)$. Total bilirubin, direct bilirubin and indirect bilirubin were reported to have increased in rat (3) but decreased in mice (46). Urea, creatinine, chloride ion, calcium ion and glucose increased as sodium ion

Table 4. Comparative haematological effects of aqueous extract of Abrus precatorius leaf

\begin{tabular}{lcc}
\hline Parameters & Adedapo et al. (2) & Saganuwan (40) \\
\hline Body weight & ND & $\uparrow$ \\
Red blood cells & $\downarrow$ & $\uparrow$ \\
Packed cell volume & $\downarrow$ & $\uparrow$ \\
Haemoglobin concentration & $\downarrow$ & NS \\
Mean Corpuscular Volume & $\downarrow$ & $\uparrow$ \\
Mean Corpuscular Haemoglobin & $\uparrow$ & $\downarrow$ \\
White Blood Cells Count & $\downarrow$ & $\uparrow$ \\
Neutrophils & $\uparrow$ & NS \\
Lymphocytes & $\downarrow$ & $\uparrow$ \\
Eosinophils & NS & $\downarrow$ \\
Monocytes & NS & $\uparrow$ \\
Basophils & ND & $\downarrow$ \\
\hline
\end{tabular}

Keys: $\mathrm{ND}=$ No data, NS=Not significant; $\uparrow=$ Increase; $\downarrow=$ Decrease 


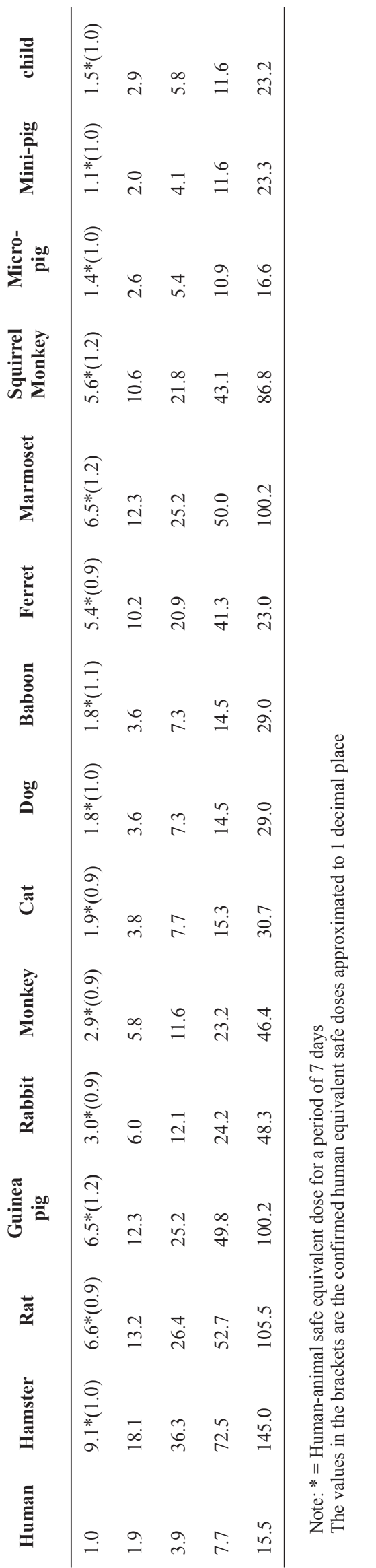


Saganuwan S.A. and Onyeyili P.A.

Table 5. Comparative biochemical effects of aqueous extract of Abrus precatorius leaf

\begin{tabular}{|c|c|c|}
\hline Parameters & Adedapo et al. (3) & Saganuwan and Onyeyili $(37,45)$ \\
\hline Alanine aminotransferase & 4 & 4 \\
\hline Aspartate aminotransferase & 4 & 4 \\
\hline Alkaline phosphate & 4 & 4 \\
\hline Cholesterol concentration & ND & NS \\
\hline Protein & 4 & $\downarrow$ \\
\hline Albumin & 4 & 4 \\
\hline Globulin & 4 & 4 \\
\hline Albumin/globulin ratio & 4 & 4 \\
\hline Urea & ND & 4 \\
\hline Creatinine & ND & 4 \\
\hline Total bilirubin & 4 & 4 \\
\hline Direct bilirubin & 4 & $\downarrow$ \\
\hline Indirect bilirubin & $\boldsymbol{4}$ & $\downarrow$ \\
\hline Glucose & ND & 4 \\
\hline Sodium ion & ND & $\downarrow$ \\
\hline Potassium ion & ND & 4 \\
\hline Calcium ion & ND & $\downarrow$ \\
\hline Chloride ion & ND & 4 \\
\hline Biocarbonate ion & ND & NS \\
\hline Phosphate ion & ND & $\downarrow$ \\
\hline
\end{tabular}

Keys: $\mathrm{ND}=$ No data, $\mathrm{NS}=$ Not significant; $\boldsymbol{4}=$ =Increase $\downarrow \downarrow$ =Decrease

and phosphate ion decreased in mice (46). Adedapo et al. (3) didn't report the effect of aqueous extract of Abrus precatorius leaf on body weight, glucose, sodium ion, potassium ion, calcium ion, chloride ion, bicarbonate ion and phosphate ion (Table 5).

\section{DISCUSSION}

The mouse-human translated $\mathrm{LD}_{50}$ of 197.9-241.5 $\mathrm{mg} / \mathrm{kg}$ body weight agrees with the report of Yamba et al. (58) indicating that the human translated $\mathrm{LD}_{50}$ should be between $10^{\text {th }}$ and $100^{\text {th }}$ of $\mathrm{LD}_{50}$ in mice. This shows that adult human is the most sensitive to acute poisoning of Abrus precatorius leaf followed by child, mini-pig, micro-pig, baboon, dog, cat, monkey, rabbit guinea pig, rat, hamster and mouse in that order (Table 1) invariably rating the extract as slightly to moderately toxic in monogastric animals $(26,40,41)$. But the calculated higher $\mathrm{LD}_{50}$ of child $(297-362.3 \mathrm{mg} / \mathrm{kg})$ in comparison with the $\mathrm{LD}_{50}$ of adult human $(197.9-241.5 \mathrm{mg} / \mathrm{kg})$ may be caused by high body surface area of the child in comparison with that of the adult. Hence the child may require more amount of the extract than the adult. Generally the child weighing $20 \mathrm{~kg}$ should have developed 28 fully metabolic enzymes. High body surface area is given low km. Connotatively, fatty individuals may be less susceptible to Abrus precatorius poisoning than lean individuals. However $12.5 \mathrm{mg} / \mathrm{kg}$ body weight that translated to $1.0 \mathrm{mg} / \mathrm{kg}$ showed no observable adverse effect when administered for a period of 3 days to Plasmodium berghei infected mice, although the dose cleared $98.7 \%$ of the parasites in the blood within 9 days after the extract treatment (47). These findings agree with the report of Saganuwan (40) indicating that the Nupe ethnic group from Bida emirate has been using Abrus precatorius leaf for the treatment of both acute and chronic malarial symptoms. The use of Abrus leaf in the treatment of malaria among Nupes is sometimes either the last option after the conventional antimalarial drugs might have failed or due to poverty. The administration of $12.5 \mathrm{mg} / \mathrm{kg}$ body weight of the extract for 7 days did not cause any observable adverse effect on the treated mice but caused slight increase in the plasma urea level $(37,45)$. Therefore $1 \mathrm{mg} / \mathrm{kg}$ body weight translated dose for a period of 3 days may be safe in human, but when administered for a period of 7 days may likely cause slight increased plasma urea in human. Hence, one-tenth safety factor of mouse therapeutic 
dose can be adopted in human, whereas the $100^{\text {th }}$ to $1000^{\text {th }}$ safety factor of Abrus precatorius leaf extract may be adopted for doses between 10 and $100 \mathrm{mg} / \mathrm{kg}$ body weight of the extract. The least sensitive animal to Abrus precatorius aqueous leaf extract in this study may be mice, followed by hamster, rat and guinea pig respectively. However, doses higher than $1.5 \mathrm{mg} / \mathrm{kg}$ may be toxic to a child. Also doses higher than $9.1,6.6,6.5,3.0,2.9,1.9,1.8,1.8,5.4,6.5$, $5.6,1.4$ and $1.1 \mathrm{mg} / \mathrm{kg}$ body weight may be toxic to hamster, rat, guinea pig, rabbit, monkey, cat, dog, baboon, ferret, squirrel monkey, micro-pig and minipig respectively (Table 3 ). Animal human equivalent dose projections can be done in three ways; doses expressed in $\mathrm{mg} / \mathrm{kg}$ body weight for the species where "the critical effect" leading to "the reference dose" are adjusted to $\mathrm{mg} / \mathrm{kg}$ body weight $\mathrm{t}^{0.75}$ to reflect the dependence of pharmacokinetic elimination on metabolic rate-which may tend to scale with (body weight) $)^{0.75}(1,34,53)$. Although when we scaled the body weight to 0.75 the estimated $\mathrm{LD}_{50 \mathrm{~s}}$ were seriously higher in comparison with 0.67 . A further adjustment factor may be applied to reflect the median human maximum tolerated dose (MTD) expected based on the identity and number of species that provided data that potentially could have been used as the basis for the reference dose (24). The expected geometric means of the ratios of human toxic potency $\left(\frac{1}{M T D}\right)$ to the toxic potency estimated from the animal experiments $\left(\frac{1}{L D_{10}}\right)$ or $\left(\frac{1}{T D L_{0}}\right)$ are based on the ratios available for each species or combination of species shown (15). Looking from the single-species analyses to the cases for which data for increasing numbers of species are available for choice of "the most sensitive", it can be seen that the geometric mean ratios of the observed human potency to the human potency projected from the animal potency per (body weight) ${ }^{0.75}$ tend to decline. This is the natural result of the fact that the lowest toxic dose inferred for data for more species will tend to make a more "conservative" prediction of human potency than when data are only available for a single animal species. Finally, the uncertainty in each type of animal-to-human toxic potency projection is inferred from variability of the ratios of the observed human potencies to the animalprojected potencies for different compounds. These variabilities are modelled as lognormal distributions with the standard deviations of the logarithms of the observed human to animal-projected potency ratios (24).

Increased $\mathrm{RBC}, \mathrm{PCV}$ and haematocrit at dose range between $25-200 \mathrm{mg} / \mathrm{kg}$ body weight showed that the plant aqueous leaf extract, have haematinic effect at lower dose levels (44). But at higher dose levels $(400-1600 \mathrm{mg} / \mathrm{kg})$, it caused haemolysis with resultant hyperbilirubinaemia (3). However, at both lower doses $(25-200 \mathrm{mg} / \mathrm{kg})$ and higher doses (400-1600 $\mathrm{mg} / \mathrm{kg}$ ) the plant leaf extract caused increase in biochemical parameters with resultant deleterious effect on kidney, heart, intestine, lung, spleen and liver. But Adedapo et al. (3) should have conducted acute toxicity study on rats to serve as a guide for their selection of therapeutic doses instead of using predetermined doses. More so, their histopathological studies were restricted to testes, kidney and liver bearing in mind the fact that the plant is organotoxic. When Saganuwan and Onyeyili (40) treated mice with $25-200 \mathrm{mg} / \mathrm{kg}$ body weight of Abrus leaf extract for 21 days, the extract caused death of some mice, most especially at higher doses $(25-200 \mathrm{mg} / \mathrm{kg})$. But, it looked strange that Adedapo et al. (3) didn't report death in their experimental animals with serious kidney and liver damage. The plant has been reported to contain toxalbumin (phytoprotein), abrin, which may be responsible for the observed toxicity effects (21). Abrin consists of abrus agglutinin, and toxic lectins [a] to [d], the five toxic glycoproteins found in the plant. Abrus agglutinin is non-toxic to animal cells but a potent haemaglutinator (7). The toxic portion of abrin is heat-stable to incubation at $60{ }^{\circ} \mathrm{C}$ for 30 minutes, but at $80{ }^{\circ} \mathrm{C}$ most of the toxicity is lost in 30 minutes (36). Although the plant, particularly the seed is known to be highly poisonous due to presence of abrin $(7,12,14,21,36)$, the leaf in the present study was observed to be slightly toxic. The incubation of the abrus leaf extract at $60{ }^{\circ} \mathrm{C}$ for several hours must have reduced the toxicity of the leaf (46). Although the extract was administered orally, abrin is very stable in the gastrointestinal tract, from where it is slowly absorbed and thereby making it less toxic (19). Abrins's toxic effect is due to its direct action on the membrane of parenchymal cells (e.g. liver, kidney cells and erythrocytes) (23) via the B chain (haptomere) that binds to galactosyl-terminated receptors on the cell membrane, which is a prerequisite for the entry of the other subunit, the A chain (effectomere). This inactivates the ribosomes, arrests protein synthesis, and causes cell death (50). The A-chain attacks the 60 s subunits of the ribosomes and by cutting out elongation $\mathrm{EF}_{2}$ stops synthesis of protein (18). So the extraction and concentration of aqueous extract of Abrus precatorius leaf at $60^{\circ} \mathrm{C}(46)$ and unknown temperature (3) must have reduced toxic effects of the leaf extract in mice and rats respectively. 


\section{CONCLUSION}

The translated mouse-human $\mathrm{LD}_{50}$ is 197.9$241.5 \mathrm{mg} / \mathrm{kg}$ body weight, showing high level of sensitivity of humans to Abrus precatorius leaf poisoning. The safe human therapeutic dose for a period of 3 days may be $1.0 \mathrm{mg} / \mathrm{kg}$ body weight. But the safe therapeutic doses for other animals are; hamster $(9.1 \mathrm{mg} / \mathrm{kg})$, rat $(6.6 \mathrm{mg} / \mathrm{kg})$, guinea pig $(6.5$ $\mathrm{mg} / \mathrm{kg}$ ), rabbit (3.0 mg/kg), monkey (2.9 mg/kg), cat $(1.9 \mathrm{mg} / \mathrm{kg})$, dog and baboon $(1.8 \mathrm{mg} / \mathrm{kg})$ and child $(1.5 \mathrm{mg} / \mathrm{kg})$ respectively. However, the administration of the safe doses for a period of 7 days may cause slight increase in the plasma urea.

\section{REFERENCES}

1. Ad Hoc Working Group (AHWG) (1992). Federal Coordinating Council for science, engineering and technology (FCCSET) Draft Report: A cross-section scaling factor for carcinogen risk assessment based on equivalence of $\mathrm{mg} / \mathrm{kg} 3$ /day. Federal Register 57: $24152-24173$.

2. Adedapo, A.A. (2002). Toxicological effects of some plants in the family euphorbiaceae in rats. PhD Thesis, University of Ibadan, Nigeria.

3. Adedapo, A.A., Omoloye, O.A., Ohore, O.G. (2007). Studies on the toxicity of an aqueous extract of the leaves of Abrus precatorius in rats. Onderstepport J Vet Res. 74, 3136. http://dx.doi.org/10.4102/ojvr.v74i1.137

4. Adelowotan, O., Aibinu, I., Adenipekun, E., Odugbemi, T. (2008). The in vitro antimicrobial activity of Abrus precatorius (L) Fabaceae extract on some clinical pathogens. Niger Postgrad Med. J. 15 (1): 32-37.

PMid:18408781

5. Anam, E.M. (2011). Anti-inflammatory activity of compounds isolated from the aerial parts of Abrus precatorius (Fabaceae). Phytomedicine 8(1): 24-27. http://dx.doi.org/10.1078/0944-7113-00001 PMid:11292235

6. Anand, R.S., Kishire, V.O., Rajkumar, V. (2010). Abrus prectorius. A phytopharmacological review. J. Pharm. Res. 3(11): 2585-2587.

7. Budavari, S. (1989). The Merak Index: An Encyclopedia of Chemicals, Drugs and Biologicals, 10th ed., Rahway, New Jersey, Merck and Co. Inc PMid:2666071

8. Burkill, H.M. (1997). The useful plant of West Tropical Africa, Vol 11, Royal Botanical Gardens, Kew.
9. Cheecke, P.R. (1998). Natural toxicants in feed, forage and poisonous plants. Interstate Publishers, Denville.

10. Cheecke, P.R., Shull, L.R. (1985). Natural toxicants in feeds and poisonous plants. The Connecticut: AVI Publishing Company.

11. Choudhari, A.B., Sayyed, N., Khairnar, A.S. (2011). Evaluation of antiserotonergic activity of ethyl acetate extract of Abrus precatorius leaves. J. Plant Res. 4(3): 570-572.

12. Davis, J.H. (1978). Abrus precatorius (Rosary pea). The most common lethal plant poison. J. Florida Med Assoc. 65, 189-191.

13. Dhawan, B.N.,Patnaik, G.K., Singh, K.K., Tandon, J.S., Rastogi RP. (1977). Screening of Indian plants for biological activity. Indian J Exp Biol. 15, 208-219. PMid:914326

14. Dreisbach, R.H., Robinson, W.O. (1987). Handbook of poisoning: prevention, diagnosis and treatment. Los Altos, Appleton and Lange, California 497.

15. Faustman, E.M., Allen, B.C., Karlock, R.J., Kimmel, C.A. (1994). Dose-response assessment for developmental toxicity. 1. Characterization of database and determination of no observed adverse effect levels. Fundamental Appl. Toxicol. 23, 478-486. http://dx.doi.org/10.1006/faat.1994.1132

16. Fernando, C. (2011). Poisoning due to Abrus precatorius (Jequirity bean). Anaesthesia 56 (12): 1178-1180.

17. Freireich, E.J., Gehan, E.A., Rall, D. (1966). Quantitative comparison of toxicity of anticancer agents in mouse, rat, hamster, dog, monkey and man. Cancer Chemother. Rep. 50, 219-244. PMid:4957125

18. Frohne, D., Pfander, H.J. (1983). A colour atlas of poisonous plants. Germany Wolfe Publishing Ltd., 291. PMid:6683299

19. Galey, F.D. (1996). Plants and other natural toxicants. In: (Smith BP. Ed), Large Animals Internal Medicine, 2nd ed., Boston: Mushby Publishers.

20. Garg, S.K. (2005). Veterinary toxicology. New Delhi CBS publishers and Distributors, p321.

21. Ghosal, S., Dutta, S.K. (1971). Alkaloids of Abrus precatorius. Phytochemistry 10(1): 195-198. http://dx.doi.org/10.1016/S0031-9422(00)90270-X

22. Hart, M. (1963). Jecquirity bean poisoning. N. Engl. J. Med. 268, 885-886. http://dx.doi.org/10.1056/NEJM196304182681608

23. Hatts, D.S., S. Goble, R. (2002). A straw-man proposal for a quantitative definition of the reference dose. DOD conference on Toxicology risk assessment, Dayton, Ohio, 25, 2001, p 1-48. 
24. Hemadari, K., Rao, S.S. (1983). Leucorrhoea and menorrhalgia, tribal medicine, Ancient Sci. Life 3, 40-41.

25. Hodge, H.C., Sterner, J.H. (1949). Toxicity rating. Am. Ind. Hyg. Assoc. Q. 10(4): 93. PMid:24536943

26. Iwu, M.M. (1993). Handbook of African medicinal plants. London: CRC Press Boca Raton Ann Arbot.

27. Kim, N.C., Kim, D.S., Kinghorn, A.D. (2002). New triterpenoids from the leaves of Abrus precatorius. Nat. Prod.Let.16 (4): 261-266. http://dx.doi.org/10.1080/10575630290020596 PMid:12168762

28. Kirtikar, K.R., Basu, B.D. (1980). Indian medicinal plants. Vol. 1, Dehra Dun: International Book Distributors.

29. Klassen, C.D. (2011). Casarett and Doall's. Toxicology: The basic science of poisoning. 6th ed., New York: Mc Graw-Hill.

30. Limmatvapirat, C., Sirisopanapom, Kittakoop, P. (2004). Antitubercular and antiplasmodial constituents of Abrus precatorius. Planta Med. 70 (3): 276-278. http://dx.doi.org/10.1055/s-2004-818924 PMid:15114511

31. Liu, C.L., Tsai, C.C., Lin, S.C. Wang, L.I., Hsu, C.I., Hwang, M.J., Lin, J.Y. (2000). Primary structure and function analysis of Abrus precatorius agglutinin A by site-directed mutagenesis, Pro (199) and amphiphilic alpha-helix $\mathrm{H}$ impairs protein synthesis inhibitory activity. J. Biol. Chem. 275 (3): 1897-1901. http://dx.doi.org/10.1074/jbc.275.3.1897 PMid:10636890

32. Mann, A., Gbate, M., Nda, Umar, A. (2003). Medicinal and economic plants of Nupeland. Bida: Jube Evans Books and Publications, p.191.

33. Mordent, J. (1986). Man versus beast: pharmacokinetic scaling inmammals. J.pharmaceut. Sci.75, 1028-1040. http://dx.doi.org/10.1002/jps.2600751104

34. Premanand, R., Ganesh, T. (2010). Neuroprotective effects of Abrus precatorius Linn. Aerial extract on hypoxic neurotoxicity induced rats. Intern. J. Chem. Pharmaceut. Sci. 1(1).

35. Rajaram, N., Janardhanan, K. (1992). The chemical composition and nutritional potential of the tribal pulse, Abrus precatorius L. plant. Foods Human Nutr. 42(94): 285-290. http://dx.doi.org/10.1007/BF02194088

36. Reagan-Shaw, S., Nihal, M., Amhad, N. (2007). Dose translation from animal to human studies revisited. The FASEBJ 22, 659-661. http://dx.doi.org/10.1096/fj.07-9574LSF PMid:17942826
37. Saganuwan, S.A., Onyeyili, P.A. (2012). Haematonic and plasma expander effects of aqueous leaf extract of Abrus precatorius in Mus musculus. Campar Clinical Pathol. 21(6): 1249-1255. http://dx.doi.org/10.1007/s00580-011-1274-8

38. Saganuwan, S.A. (2011). A modified arithmetical method of Reed and Muench for determination of a relatively ideal median lethal dose (LD50). Afr. J. Pharm. Pharmacol. 5(12): 1543-1546. http://dx.doi.org/10.5897/AJPP11.393

39. Saganuwan, S.A. (2012). Toxicological and antimalarial effect of aqueous leaf extract of Abrus precatorius (Jacqurity bean) in Swiss albino mice. PhD Thesis, Usmanu Danfodiyo University, Sokoto Nigeria.

40. Saganuwan, S.A. (2012b). Principles of pharmacological calculations. 1st ed., Zaira: Ahmadu Bello University Press Ltd.

41. Saganuwan, S.A., Gulumbe, M.L. (2005a). In vitro antimicrobial activities testing of Abrus precatorius cold water leaf extract on Salmonella typhimurium, Escherichia coli and Klebesiella pneumoniae. J. Sci. Technol. Res. 4(3): 70-73.

42. Saganuwan, S.A., Gulumbe, M.L. (2005b). In vitro antimicrobial activities testing of Abrus precatorius cold water leaf extract on Streptococcus pyogenes and Streptococcuspneumoniae. Proc 2nd Annu Conf Nigerian Soc. Indigen Knowl Dev., 9th-12th Nov., Cross River State Univ. Technol Obubra, 93-97.

43. Saganuwan, S.A., Onyeyili, P.A., Etuk, U.E. (2009). Acute toxicity and haematological studies of aqueous extract of Abrus precatorius leaf in Mus Musculus, African Education Initiative Conf. p65.

44. Saganuwan, S.A., Onyeyili, P.A., Suleiman, A.O. (2011). Comparative toxicological effects of orally and intraperitoneally administered aqueous extracts of Abrus precatoriusleaf in Mus musculis. Herba Polonica 57(3): 32-44.

45. Saganuwan, S.A., Onyeyili, P.A. (2010). Biochemical effects of aqueous leaf extract of Abrus precatorius (Jecurity bean) in Swiss albino mice. Herba Polonica 56(3): 63-80.

46. Saganuwan, S.A., Onyeyili, P.A., Ameh, I.G., Etuk, E.U. (2011). In vivo antiplasmodial activity by aqueous extract of Abrus precatorius in mice. Rev. Latinoamer. Quin. 39(1-2): 32-34.

47. Sawyer, N., Ratain, M.J. (2001). Body surface area as a determinant of pharmacokinetics and drug dosing. Invest New Drugs 19, 171-177. http://dx.doi.org/10.1023/A:1010639201787 PMid:11392451

48. Sofi, M.S., Sateesh, M.K., Bashir, M.,Harish, G., Lakshmeesha, T.R., Vedashree, S., Vedamurthy, A.B. (2012). Cytotoxic and pro-apoptotic effects of Abrus precatorius $\mathrm{L}$. on human metastatic breast cancer cell line, NDA-NB-231. Cytotechnology 
49. Stirpe, F., Barbieri, L. (1986). Symposium: Molecular mechanisms of toxicity, toxic lectins from plants. Human Toxicol. 5(2): 108-109.

http://dx.doi.org/10.1177/096032718600500208

50. Sylva, M. (1998). Interspecies allometric scaling in pharmacokinetics of drugs. Acts Pharm Hung. 68 (6): 350-354.

51. Taur, D.J., Patil, R.Y. (2011). Effect of Abrus precatorius Leaves on milk induced leukocytosis and eosinophilia in the management of asthma. Asian Pacific J. Tropical. 1(1): 40-42. http://dx.doi.org/10.1016/S2221-1691(11)60119-6

52. Travis, D.C., White, R.K., Ward, R.C. (1990). Interspecies extrapolation of pharmacokinetics. J. Theoretical Biol. 142, 285 - 304. http://dx.doi.org/10.1016/S0022-5193(05)80554-5

53. Tripathi, S., Maith, T.K. (2005). Immunomodulatory role of native and heat denatured agglutinin from Abrus precatorius. Int. J. Biochem. Cell Biol. 37(13): 451-462. http://dx.doi.org/10.1016/j.biocel.2004.07.015 PMid:15474989

54. US Environmental Protection Agency (USEPA) (1986). Guideline for carcinogen risk assessment. Fed Regist 51: 3392-4003.
55. Wambebe, C., Amosun, S.L. (1984). Some neutromuscular effects of crude extracts of the leaves of Abrus precatorius. J. Ethnopharmacol. 11(1): 49-58. http://dx.doi.org/10.1016/0378-8741(84)90095-3

56. Watt, J.M., Breyer-Brandiwijk, A. (1962). The medicinal poisoning plants of Southern and Eastern Africa, 2nd ed., London: Livingstone publishers. PMCid:PMC1957435

57. Xiao, Z.H., Wang, F.Z., Sun, A.J. (2011). A new triterpenoid saponin from Abrus precatorius Linn. Molecules 17(1): 295-302.

http://dx.doi.org/10.3390/molecules 17010295

PMid:22210168

58. Yamba, O., Innocent, P.G., Odille, G.N. (2007). Biological and toxicological study of aqueous rootextract from Mitragyna inermis (Wild Okt) Rubiacea. Int. J. Pharmacol. 3(1): 80-85

http://dx.doi.org/10.3923/ijp.2007.80.85 